\title{
Efektivitas Akun Komunitas Instagram @1000_guru_bdg dalam Pemenuhan Kebutuhan Informasi Followers
}

\author{
Novia Dianita Andiny ${ }^{1}$, Iis Kurnia Nurhayati ${ }^{2}$, dan Gartika Rahmasari ${ }^{3}$ \\ ${ }^{1,2}$ Universitas Telkom \\ ${ }^{3}$ Universitas BSI
}

\begin{abstract}
ABSTRAK
Akun komunitas Instagram @1000_guru_bdg merupakan inspirasi bagi pendidikan pedalaman dan pembatasan negeri di Indonesia. Akun@1000_guru_bdg dikatakan berbeda karena akun ini berisi tentang kegiatan mengajar sambil berjalan-jalan yang dilihat dengan adanya salah satu aksi kegiatan sosial komunitas ini, yaitu "Traveling \& Teaching". Pada kegiatan "Traveling \& Teaching", komunitas ini mengajak volunteers (relawan) untuk bergabung, dimana volunteers dikenakan biaya yang dapat dikatakan cukup mahal dan menyasar anak muda. Penelitian ini bertujuan untuk mengetahui seberapa tinggi efektivitas kegiatan "Traveling \& Teaching" dalam pemenuhan kebutuhan informasi akun komunitas Instagram @1000 guru bdg, dengan menggunakan metode penelitian kuantitatif deskriptif dan paradigma positivisme. Populasi pada penelitian ini adalah followers akun komunitas Instagram @1000_guru_bdg dan sampel yang diambil peneliti sebanyak 100 responden dengan menggunakan teknik analisis data, yaitu analisis deskriptif, uji normalitas, analisis koefisien determinasi, dan uji hipotesis. Hasil dari penelitian ini adalah (1) persentase efektivitas kegiatan "Traveling \& Teaching" tergolong tinggi dengan kategori sudah efektif, (2) persentase kebutuhan informasi aktivitas "Traveling \& Teaching" tergolong tinggi dengan kategori sudah efektif, dan (3) persentase efektivitas kegiatan "Traveling \& Teaching" pada akun komunitas Instagram @1000_guru bdg berpengaruh signifikan dalam pemenuhan kebutuhan informasi followers dengan persentase tinggi. Hal ini dapat menunjukkan bahwa efektivitas pada akun komunitas Instagram @1000_guru_bdg sudah efektif terhadap pemenuhan kebutuhan informasi followers.
\end{abstract}

Kata-kata Kunci: @1000_guru_bdg; efektivitas; instagram; komunitas; pemenuhan kebutuhan informasi

\section{The Effectiveness of @1000_guru_bdg_Community Instagram Account in Fulfilling Followers Information Needs}

\begin{abstract}
Instagram account of @1000 guru bdg community is an inspiration for the inland education restrictions and the restriction in in Indonesia. @1000 guru_bdg account is said to be different because this community do the teaching while traveling. One of their programs is "Traveling \& Teaching". In this "Traveling \& Teaching" program, the community invited volunteers to join, however volunteers should pay an expensive enough fee due and the target is mostly teenagers. This research aims to find out how effective "Traveling \& Teaching" program in fulfilling the information needs of @1000_guru_bdg community_nstagram account,by using descriptive quantitative research method and utilizing the paradigm of positivism. The population in this research is the followers of @1000_guru_bdg community Instagram account, and samples taken were as many as 100 respondents by using techniques of data analysis i.e. descriptive analysis, test analysis, determination of the coefficient of normality, and the hypothesis test ( $t)$. The result of the research are (1) the percentage of the utilization of the activities of the "Traveling \& Teaching" is considered high and effective, (2) the percentage of the needs of the activities information of "Traveling \& Teaching" is considerd high and effective, and (3) the percentage of the utilization of the activities of "Traveling \& Teaching" in community account Instagram@1000_guru_bdg is significantly influential in fulfillment of information needs with a high percentage of followers. The results show that the utilization of @1000_guru_bdg account is already effective in fulfilling the follower's need.
\end{abstract}

Keywords: @1000_guru_bdg; community; effectiveness; fulfillment information; instagram

Korespondensi: Novia Dianita Andiny. Universitas Telkom. Jl.Telekomunikasi No.01, Terusan Buah Batu, Sukapura, Dayeuhkolot, Bandung, Jawa Barat 4025.Email: noviaandiny@yahoo.com 


\section{PENDAHULUAN}

Internet berperan penting dalam kebutuhan komunikasi dan informasi. Kebanyakan orang saat ini terkoneksi dengan Internet untuk menggunakan jejaring sosial. Menurut Putri, Hamdan, dan Yulianti (2017), fenomena penggunaan internet akan memberikan efek, yaitu terjadinya konvergensi media. Peningkatan efek Internet ini telah didorong oleh sejumlah faktor. Pertama, infrastruktur yang mulai meningkat dan merata, dan kedua, ketersediaan pada perangkat mobile semakin banyak dan mudah terjangkau dalam penggunaannya. Saat ini, muncul berbagai akun yang mengatasnamakan komunitas, seperti komunitas Whatsapp di Facebook, komunitas Android di Twitter, dan Komunitas 1000 guru Bandung di Instagram. Salah satu media sosial saat ini yang sering digunakan adalah Instagram. Masyarakat Indonesia sangat aktif dalam menggunakan media sosial Instagram, dan respons pengguna terhadap media sosial Instagram pun cukup bagus. Peningkatan minat masyarakat mengenai Instagram memunculkan akun komunitas pendidikan seperti@1000 guru_bdg,@pengajarmuda,dan@1001buku.

Pendidikan saat ini sangat jauh berbeda dibandingkan dengan tahun-tahun sebelumnya, salah satunya dilihat dari biaya sekolah yang meningkat. Selain itu, banyak anak pedalaman yang kesulitan mendapatkan pendidikan. Hal ini pernah diberitakan oleh Kompas pada tanggal 27 Agustus 2009. Dalam berita tersebut disebutkan bahwa di Kalimantan Selatan sendiri ada 2.952 sekolah yang kondisinya mulai lapuk karena sekolah-sekolah tersebut pernah mengalami perbaikan dari sejak pertama kali dibangun. Bangunan-bangunan sekolah tersebut rawan terbakar pada musim panas, dan juga rawan ambruk jika ditiup angin hujan yang kencang. Dari keseluruhan bangunan sekolah di Kalimantan Selatan yang kondisinya memprihatinkan, sekitar 10.442 ruang kelas memerlukan renovasi, yang terdiri atas 4.403 ruang kelas mengalami kerusakan berat dan 6.039 diantaranya mengalami kerusakan ringan. Maka, dapat disimpulkan bahwa pemerintah kurang memberikan perhatian terhadap masyarakat pedalaman dalam hal pendidikan, sehingga masyarakat pedalaman tidak bisa melakukan apa-apa karena tidak memiliki biaya untuk merenovasi bangunan sekolah tertentu (Annisa, 2014, Potret Pendidikan di Indonesia).

Dengan adanya berita mengenai kurangnya fasilitas bagi anak pedalaman, muncul banyak komunitas-komunitas yang peduli akan hal ini. Di Instagram sendiri, terdapat komunitas @pengajarmuda yang merupakan komunitas untuk membantu mengisi adanya kekurangan guru sekolah dasar, khususnya di daerah yang terpencil dengan mengirimkan para lulusan 
terbaik perguruan tinggi yang ada di Indonesia.

Para pengajar muda ini telah mendapatkan pelatihan pengajaran secara intensif untuk menguasai teknik kepengajaran dan kepemimpinan untuk bekerja sebagai guru di pedalaman selama kurang lebih satu tahun. Akun @pengajarmuda memiliki jumlah followers sebanyak 10.200. Selain itu, ada komunitas @1000_guru_bdg yang peduli terhadap pendidikan di pedalaman dan perbatasan di Indonesia, dengan jumlah followers sebanyak 10.600. Akun komunitas Instagram@1000_ guru_bdg merupakan cabang dari komunitas 1000 guru.

Seperti yang ditulis dalam website seribuguru.org tahun 2016, akun komunitas 1000_guru merupakan akun yang memberitakan keadaan realita pendidikan di pedalaman pelosok negeri melalui media sosial, salah satunya yaitu Instagram. Namun, kegiatannya saat ini berkembang dengan melakukan aksi sosial nyata dengan cara turun langsung membantu pendidikan anak-anak pedalaman negeri. Komunitas 1000 guru sudah tersebar di 35 wilayah di Indonesia, salah satunya di Bandung. Berbagai kegiatan aksi dilakukan oleh komunitas 1000 guru, yang pertama, memberikan beasiswa guru pedalaman, yaitu dengan memberikan beasiswa kepada guru lokal yang memiliki keinginan yang tinggi namun hanya merupakan lulusan SMA. Oleh sebab itu, komunitas 1000 guru memberikan beasiswa kepada guru lokal di daerah tersebut, kedua, kegiatan traveling and teaching yang mengajak kalangan anak muda dengan latar belakang yang beragam untuk bergabung dengan komunitas 1000 guru, ketiga, moral campaign “Hormati Gurumu?”, yaitu guru adalah ujung tombak pendidikan supaya anak-anak harus menghormati seorang guru (Seribuguru, 2016, Traveling \& Teaching).

Dibandingkan dengan akun Instagram serupa lainnya yang juga merupakan komunitas peduli pendidikan di Indonesia, akun komunitas @1000_guru_bdg dapat dikatakan berbeda karena akun ini mengajar sambil berjalanjalan dilihat dengan salah satu aksi kegiatan sosial komunitas @1000_guru_bdg yaitu traveling \& teaching karena komunitas ini dipertemukan awalnya dikarenakan hobi yang sama yaitu traveling. Selain itu, komunitas ini juga mengajak siapa saja yang ingin ikut berpartisipasi, khususnya anak-anak muda, dengan bergabung dan mem-follow akun tersebut tanpa harus memiliki pendidikan yang tinggi. Oleh karena, itu tidak heran jika akun komunitas Instagram ini memiliki followers terbanyak dibandingkan dengan komunitas sejenis lainnya.

Komunikasi pada akun komunitas Instagram ini sangatlah penting dikarenakan setiap kegiatan yang di-sounding melalui 
akun ini. Masyarakat juga dapat mengetahui informasi terbaru tentang kegiatan akun komunitas Instagram @11000_guru_bdg ini.

Oleh karena itu, peneliti ingin mengetahui seberapa efektif akun komunitas Instagram @1000_guru_bdg dalam pemenuhan kebutuhan informasi followers mengenai pendidikan di Indonesia. Penelitian ini dilakukan menggunakan teori media massa, media baru, media sosial, Instagram, efektivitas, uses and gratifications, dan hipotesis penelitian. Dalam buku teori komunikasi massa yang ditulis oleh John Vivan, disebutkan bahwa media massa merupakan sarana yang membawa pesan. Media massa terdiri dari media cetak dan media elektronik. Sejalan dengan adanya perkembangan teknologi komunikasi saat ini, media massa pun semakin canggih dan kompleks, serta memiliki kekuatan yang lebih dari masa-masa sebelumnya, terutama dalam menjangkau komunikan. Media massa saat ini ditambah dengan munculnya Internet membuat adanya media baru. Media baru adalah konsep yang menjelaskan kemampuan media yang dilengkapi dukungan perangkat digital. Dengan demikian, pembaca dapat mengakses konten apa saja, dimana saja sehingga memberikan kesempatan bagi siapa baik, sebagai penerima atau pengguna untuk berpartisipasi secara aktif, interaktif, dan kreatif terhadap umpan balik pesan yang pada gilirannya membentuk komunitas atau masyarakat "baru" melalui isi media. Keberhasilan media baru membuat penggunaan media ini sangatlah penting saat ini karena kemudahannya dalam berkomunikasi dan pencarian informasi. Menurut Liliweri (2015), media baru mengubah makna jarak geografis, danjuga memungkinkan terjadinya pertambahan volume informasi secara besar-besaran. Selain itu, media baru juga memungkinkan terjadinya bentuk komunikasi yang sebelumnya terpisah dan tumpang tindih menjadi komunikasi interkoneksi. Media baru memasuki fase yang disebut dengan web 2.0 yang membuat semuanya menjadi lebih interaktif. Sebagai salah satu bentuk media komunikasi, Internet memiliki peran yang penting, yaitu sebagai alat untuk yang digunakan komunikator pesan untuk mengirimkan pesan kepada komunikan pesan. Salah satu media baru saat ini adalah media sosial. Dalam buku komunikasi antar personal, Liliweri (2015) menyatakan bahwa media sosial merupakan sarana interaksi bagi para pengguna melalui "sharing" informasi dan ide-ide; interaksi dilakukan menggunakan jaringan Internet yang diwadahi oleh suatu komunitas virtual. Dilihat dari perkembangan hubungan individu dengan perangkat media, media sosial dapat didefinisikan sebagai kumpulan perangkat dengan media Internet yang memungkinkan seseorang untuk berkomunikasi, berkumpul, dan berinteraksi 
dengan pengguna lainnya. Pengoperasian media biasanya mengacu pada penggunaan asas $4 C$, yaitu Context, Communication, Collaboration, dan Connection. Context mengacu pada cara atau bentuk dalam menyampaikan suatu pesan kepada khalayak. Communication mengacu pada praktek penyampaian dan pembagian, juga proses mendengarkan, merespons, dan mengembangkan pesan kepada khalayak. Kemudian, Collaboration mengacu pada kerjasama yang terjadi antara pemberi dan penerima pesan sehingga pesan yang disampaikan menjadi lebih efektif dan efisien. Terakhir, Connection mengacu pada hubungan yang terjadi antara pemberi dan penerima pesan, keduanya berperan penting dalam menyampaikan pesan kepada khalayak dikarenakan setiap poin 4C tersebut memiliki peran dalam memberikan informasi yang baik dan benar. Media sosial dapat membuat pengguna tidak hanya menjadi penerima informasi, tapi juga menjadi pemberi informasi kepada pengguna lainnya. Akun komunitas Instagram@1000_guru_bdg menjadi salah satu pemberi informasi kepada pengguna lainnya mengenai akun peduli pendidikan pedalaman. Menurut dailysocial.id, Instagram didefinisikan sebagai aplikasi mobile berbasis IOS, Android dan Windows phone, dimana pengguna dapat membidik, mengedit dan mengunggah (posting) gambar atau video ke laman utama Instagram atau media sosial lainnya. Foto atau video yang telah dibagikan pengguna dapat muncul pada feed akun followers. Awalnya, Instagram dikembangkan oleh Burbn, Inc, sebuah start up yang digawangi oleh Kevin Systrom dan Mike Krieger. Instagram menggunakan istilah following dan followers dalam sistem pertemanannya. Following mengacu pada kegiatan mengikuti pengguna, dan follower adalah istilah yang mengacu pada pengguna lain mengikuti suatu akun pengguna. Selain itu, setiap pengguna dapat melakukan interaksi dengan memberi komentar ataupun respons suka terhadap suatu foto atau video yang dibagikan. Ada banyak fitur yang dapat digunakan Instagram, seperti fitur kamera. Selain dapat mengunggah foto dari galeri, pengguna juga dapat membidik atau merekam suatu momen secara langsung menggunakan fitur kamera ini. Foto atau video dapat diedit, diberi caption, lalu dibagika. Di dalam fitur kamera, terdapat tool editor yang dapat digunakan untuk mengedit foto yang diambil melalui perangkat kamera. Didalamnya, terdapat 10 tool editor tingkat lanjut yang dapat digunakan untuk mengatur ulang pencahayaan, kontras, dan saturasi, yang dapat digunakan dengan mudah. Selain itu, Instagram juga memiliki fitur tag dan hashtag yang berfungsi untuk menandai followers lain atau mengelompokkan foto dalam satu table. Kemudian, fitur caption berfungsi seperti 
deskripsi foto atau video dimana pengguna dapat menambahkan kata-kata mengenai foto yang diunggah. Pengguna Instagram juga dapat berbagi foto atau video ke media sosial lainnya seperti Facebook dan Twitter. Dengan demikian, fitur-fitur yang ada dalam Instagram dapat memengaruhi visual dalam penyebaran informasi.

Tentang komunitas, Rulli Nasrullah (2014) menyatakan bahwa terdapat banyak teori yang membahas definisi komunitas. Secara umum, konsep komunitas muncul dan mengacu pada sekelompok orang. Komunitas terbentuk atas dasar adanya kesamaan, dimana terjadi interaksi sosial diantara orang-orang berkumpul dalam komunitas tersebut, dan juga terdapat wilayah-wilayah individu yang terbuka yang memungkinkan untuk diisi oleh anggota kelompok lainnya. Salah satu bentuk komunitas adalah komunitas virtual. menurut Abrar (2003), komunitas virtual adalah suatu kelompok orang yang terbiasa menggunakan multimedia dalam berkomunikasi. Dengan terbiasa menggunakan multimedia, terbiasa juga dengan menggunakan virtual reality. Virtual reality merujuk pada keadaan dimana seseorang individu dengan cara menghubungkan dirinya ke komputer dan Internet. Bagi para anggota komunitas virtual tidak mempersoalkan semua atau tidak. Bagi anggota komunitas, yang terpenting adalah bisa mengaktualisasikan diri dan bisa memuaskan kerinduan dan kebutuhan informasi. Komunikasi virtual dilakukan tanpa harus berada di satu tempat dan waktu yang sama, tapi komunikasi tersebut dilakukan dengan membutuhkan jejaring Internet. Akun komunitas Instagram @1000_guru_bdg merupakan salah satu komunitas yang berdiri dalam bentuk virtual.

Berdasarkan pemaparan tersebut, peneliti tertarik untuk membuat suatu penelitian dengan judul "Efektivitas Akun Komunitas Instagram @1000_Guru_Bdg_Dalam Pemenuhan Kebutuhan Informasi Followers".

\section{METODE PENELITIAN}

Penelitian ini menggunakan metode penelitian kuantitatif deskriptif. Menurut Salim (2001: 39), salah satu paradigma yang dapat digunakan dalam penelitian kuantitatif adalah positivisme, dimana positivisme merupakan suatu keyakinan dasar yang berakar dari paham ontologi realisme. Dalam ontology realisme, dikatakan bahwa realitas merupakan kenyataan yang berjalan sesuai dengan hukum alam. Dalam hal ini, penelitian yang dilakukan dengan pendekatan positivisme memiliki tujuan untuk membeberkan kebenaran realitas yang ada, dan bagaimana realitas tersebut berjalan. Menurut paradigma positivistik (fakta sosial), realitas merupakan sesuatu yang bersifat empiris atau benar-benar nyata, dan dapat diamati. Dalam 
suatu penelitian, peneliti dan objek penelitian bersifat independen dan melakukan interaksi satu dengan yang lain. Penelitian dilakukan dengan mengadakan percobaan atau manipulasi untuk mengontrol objektivitasnya. Berdasarkan pemaparan tersebut, dapat disimpulkan bahwa paradigma positivisme adalah suatu kejadian dimana kejadian tersebut benar-benar terjadi dan dapat dibuktikan.

Penelitian ini merupakan penelitian dengan menggunakan metode kuantitatif. Menurut Sukmadinata (2013), metode kuantitatif didasarkan pada filsafat positivisme berfokus pada fenomena objektivitas desain penelitian dengan menggunakan angka-angka, pengolahan statistik struktur, dan percobaan terkontrol. Selain kuantitatif, peneliti ini juga menggunakan metode deskriptif. Metode penelitian deskriptif adalah penelitian yang tidak melakukan pembandingan dan menggunakan variabel lain atau hipotesis yang dirumuskan untuk menjelaskan suatu fenomena atau menjawab permasalahan taksiran (Siregar, 2013: 39). Penelitian ini dilakukan dengan melakukan survei. Penelitian survei adalah penelitian yang dilakukan dengan tidak menggunakan perubahan terhadap variabel-variabel yang diteliti (Siregar, 2013: 4). Penelitian survei dilakukan baik menggunakan teknik wawancara maupun kuisioner. Namun, penelitian ini menggunakan survei untuk pengumpulan data menggunakan kuisioner.

Subjek penelitian adalah orang yang diharapkan dapat memberikan sebuah keterangan tentang suatu fakta atau pendapat (Arikunto, 2007: 152). Subjek penelitian berperan penting dalam suatu penelitian. Subjek penelitian harus ditentukan sebelum peneliti siap melakukan pengumpulan suatu data. Subjek penelitian dapat berupa benda, hal atau orang. Subjek dalam penelitian ini adalah followers akun komunitas Instagram@1000_ guru_bdg.

Selain subjek penelitian, suatu penelitian harus menentukan objek penelitian. Objek penelitian adalah sesuatu yang ditetapkan oleh peneliti untuk dipelajari, yang menghasilkan informasi tentang hal tersebut, dan pada akhirnya peneliti menarik kesimpulan tentang hal tersbeut (Sugiyono, 2014: 38). Objek penelitian ini adalah efektivitas akun komunitas Instagram@1000_guru_bdg dalam kegiatan "Traveling \& Teaching". Akun komunitas Instagram @1000_guru_bdg ini merupakan salah satu akun penyedia informasi bagi pendidikan di pedalaman di Indonesia. Akun ini dibentuk pada tanggal 22 Agustus 2012 oleh Jemi Ngadiono dan sudah memiliki 10.600 followers. Akun tersebut menyediakan berbagai informasi mengenai kegiatan-kegiatan yang akan dilakukan di daerah pedalaman, salah satunya untuk belajar bersama anak- 
anak dari pedalaman tersebut. Kegiatan ini bertujuan untuk mengajak orang-orang untuk peduli kepada anak-anak khususnya didaerah pedalaman dengan menjadi volunteer. Kegiatan volunteer pada umumnya dapat diikuti dengan tanpa mengeluarkan biaya. Namun pada komunitas ini, volunteer diminta mengeluarkan biaya sebesar Rp 450.000 yang sudah termasuk donasi, transportasi, makan, pin, sticker, tas, t-shirt dan sertifikat. Seperti diketahui bersama, kata "volunteer" memiliki arti relawan, dimana kebanyakan kegiatan tersebut dilakukan dengan tanpa dipungut biaya atau tidak mengeluarkan biaya sebanyak mungkin.

Selain objek penelitian, penelitian ini menggunakan variable.Variabel adalah suatu konstruk yang sifatnya telah diberi angka (kuantitatif), atau juga diartikan variabel adalah draft yang mempunyai bermacam-macam nilai, berupa kuantitatiF maupun kualitatif yang dapat berubah-ubah nilainya (Siregar, 2013: 10). Alat ukur yang digunakan yaitu dengan menggunakan uji validitas dan reliabilitas. Uji reliabilitas dapat dilakukan dengan populasi dan sampel yang sudah ditentukan. Di sisi lain, kuesioner yang didistribusikan dihitung dengan menggunakan skala likert. Skala likert adalah suatu skala yang digunakan untuk menghitung sikap, pendapat, dan persepsi seseorang tentang suatu objek atau fenomena tertentu. Skala likert memiliki dua bentuk pernyataan, yaitu: pernyataan positif dan negatif. Jawaban responden memiliki susunan dari sangat positif hingga sangat negatif. Pernyataan positif diberi skor 5, 4, 3, 2, dan 1, sedangkan bentuk pernyataan negatif diberi skor 1, 2, 3, 4, dan 5. Bentuk jawaban skala likert terdiri dari sangat setuju, setuju, ragu-ragu, tidak setuju, dan sangat tidak setuju. Namun untuk mempermudah dalam memilih jawaban kuisioner, menurut Sugiyono (2014: 93) alternative untuk menghindari adanya error of central tendency dimana responden cenderung untuk melakukan penilaian yang sifatnya rata-rata atau netral sehingga akan sulit untuk dianalisis, maka jawaban dibuat dalam 4 (empat) skala untuk menghindari adanya error of central tendency. Responden akan diberikan pilihan jawaban yaitu: sangat setuju, setuju, tidak setuju, dan sangat tidak setuju.

Populasi penelitian merupakan keutuhan dari objek penelitian yang dapat berupa manusia, hewan, tumbuh-tumbuhan, udara, gejala, nilai, peristiwa, sikap hidup dan sebagainya (Siregar, 2013: 30). Populasi dalam penelitian ini adalah followers akun komunitas Instagram @1000 guru_bdg.

Sampel adalah suatu langkah pengambilan data di mana hanya sebagian populasi saja yang dijangkau dan dipergunakan untuk menentukan sifat serta ciri yang dikehendaki dari suatu populasi. sampel yang diambil sebanyak 100 responden dengan menggunakan teknik analisis 
data yang digunakan yaitu analisis deskriptif, uji normalitas, analisis koefisien determinasi, dan uji hipotesis $(\mathrm{t})$.

Data adalah bahan mentah yang perlu diolah sehingga mewujudkan informasi atau keterangan (Siregar, 2013: 16). Data dapat berupa informasi kualitatif atau kuantitatif. Selain itu, ada juga yang disebut data primer dan data sekunder. Data primer adalah data yang dikumpulkan secara sendiri oleh peneliti langsung dari sumber pertama atau tempat objek penelitian dilakukan. Data primer yang terdapat dalam penelitian ini menggunakan kuesioner. Kuesioner atau angket adalah suatu teknik pengumpulan informasi yang mengizinkan analis mempelajari sikap-sikap, keyakinan, perilaku, dan karakter beberapa orang utama di dalam organisasi yang terdorong oleh sistem yang diajukan atau oleh sistem yang sudah ada. Kemudian, data sekunder adalah data yang dikeluarkan atau digunakan oleh organisasi yang bukan pengolahannya. Data sekunder dalam penelitian ini diperoleh dari penelitian terdahulu, internet, buku, serta informasi lainnya yang menunjang penelitian ini.

Uji validitas adalah membuktikan sejauh mana suatu alat ukur mampu mengukur apa yang ingin diukur. Uji validitas digunakan untuk mengukur kevalidan suatu kuesioner. Setelah membuat kuesioner, langkah selanjutnya yang harus dilakukan peneliti yaitu menguji apakah kuesioner yang dibuat tersebut valid atau tidak.

Reliabilitas adalah alat ukur yang dapat dilakukan baik secara eksternal maupun internal. (Siregar, 2013: 46-55). Uji reliabilitas digunakan untuk mengetahui sejauh mana hasil pengukuran tetap dalam taraf konsisten, apabila dilakukan pengukuran dua kali atau lebih terhadap gejala yang sama dengan menggunakan alat pengukur yang sama pula. Uji reliabilitas dapat digunakan secara eksternal maupun internal. Secara eksternal, pengujian ini dapat dilakukan dengan cara test-retest, equivalent, dan gabungan keduanya. Secara internal, reliabilitas alat ukur dapat diuji dengan membedah konsistensi butir-butir yang ada pada instrument dengan teknik tertentu. Pada penelitian ini, uji reliabilitas dilakukan dengan menggunakan teknik Alpha Cronbach.

Teknik analisis data yang digunakan yaitu menggunakan analisis deskriptif, rank order mean, uji normalitas, analisis koefisien determinasi, hipotesis (uji t). Analisis deskriptif menurut (Sugiyono, 2014: 206) yaitu dengan menganalisa data dengan cara mendeskripsikan atau menggambarkan data yang telah terkumpul sebagaimana adanya tanpa bermaksud membuat adanya kesimpulan yang berlaku untuk mendeskripsikan data yang telah terkumpul dari kuesioner mengenai tanggapan responden terhadap efektivitas akun komunitas Instagram@1000_guru_bdg dalam pemenuhan 
kebutuhan informasi followers mengenai kegiatan "Traveling \& Traching". Peneliti menggunakan persentase analisis deskriptif untuk mendapatkan hasil mengenai variabel efektivitas akun komunitas Instagram @1000 guru_bdg (X) dan pemenuhan kebutuhan informasi (Y) dengan menggunakan kuesioner sebagai teknik analisis data. Analisis rank order mean atau garis kontinum yaitu dengan menggunakan metode perhitungan statistik yang digunakan untuk mengukur tingkat efektivitas. Untuk mengetahui efektivitasnya, maka peneliti melakukan pengukuran menggunakan angket atau kuesioner, dimana masing-masing pernyataan disertai dengan empat kemungkinan jawaban yang harus dipilih. Menurut Atmaja (2011: 47), Uji normalitas adalah proses pengujian yang dilakukan untuk menguji apakah dalam sebuah model regresi, variabel bebas, variabel terikat atau keduanya memiliki distribusi normal atau tidak normal. Model regresi yang baik adalah distribusi data normal atau mendekati data normal. Untuk mengetahui hal tersebut digunakan uji kolmogorov-smirnov. Data dikatakan normal bila nilai signifikan lebih besar dari 0,05. Deteksi normalitas dilakukan dengan melihat grafik normal probability plot. Dasar pengambilan keputusannya yaitu jika data tersebut menyebar di sekitar garis diagonal dan mengikuti arah garis diagonal, maka model regresi memenuhi asumsi normalitas dan jika data tersebut menyebar jauh dari garis diagonal dan atau tidak mengikuti arah garis diagonal, maka model regresi tidak memenuhi asumsi normalitas. Analisis koefisien determinasi adalah untuk memahami seberapa baik variabel bebas (X) menjelaskan variabel terikat (Y) (Sugiyono, 2014:231). dalam Analisa regresi dimana hal yang ditunjukkan oleh besarnya koefisien determinasi antara nol dan satu. Koefisien determinasi nol membuktikan variabel independen sama sekali tidak berpengaruh terhadap variabel dependen, selain itu koefisien determinasi dipergunakan untuk memahami persentase perubahan variabel terikat $(\mathrm{Y})$ yang disebarkan oleh variabel bebas (X). Hipotesis (Uji t) menurut (Sugiyono, 2014: 302) yaitu untuk menguji seberapa besar hubungan variabel-variabel independen yakni Efektivitas Akun Komunitas Instagram @1000_guru_bdg (X) yang meliputi pemahaman, kepemenuhan kesenangan, memenuhi sikap, dan tindakan terhadap pemenuhan kebutuhan informasi followers kegiatan "Traveling \& Teaching" (Y) digunakan uji t.

\section{HASIL DAN PEMBAHASAN}

Hasil penelitian yang didapat oleh penulis dalam efektivitas akun komunitas Instagram @1000_guru_bdg, peneliti meneliti followers akun komunitas ini yang pernah berpartisipasi dalam mengikuti kegiatan "Traveling \& 
Teaching". Diperoleh hasil bahwa kegiatan yang diadakan oleh akun komunitas Instagram @1000_guru_bdg ini didominasi oleh perempuan yaitu sebanyak $58,0 \%$ dan sisanya merupakan pria sebanyak $42,0 \%$ sehingga jika dilihat dari usia, sebagian besar responden perempuan dengan usia 21-26 tahun.

Secara umum, efektivitas akun komunitas Instagram @1000_guru_bdg dalam pemenuhan kebutuhan informasi followers mengenai kegiatan "Traveling \& Teaching" sudah efektif. Untuk mengetahui penelitian ini lebih lanjut, maka peneliti menggunakan dua teori yaitu teori efektivitas (Mulyana) dan teori uses and gratifications (Katz, Gurevitch, dan Haas). Penelitian ini menggunakan variabel efektivitas akun komunitas Instagram@1000_guru bdg dengan sub variabel pemahaman, kesenangan, memenuhi sikap, dan tindakan. Serta variabel pemenuhan kebutuhan informasi (uses and gratification) dengan sub variabel kebutuhan kognitif, kebutuhan afektif, kebutuhan integrasi personal, kebutuhan integrasi sosial, dan kebutuhan berkhayal.

Analisis deskriptif adalah analisis data yang dilakukan dengan cara mendeskripsikan atau menggambarkan data yang telah terkumpul sebagaimana adanya tanpa bermaksud membuat kesimpulan yang berlaku untuk umum atau generalisasi (Sugiyono, 2014: 206). Data yang diperoleh dari hasil kuesioner penelitian ini yakni sejumlah skor yang diperoleh dari jawaban responden atas pertanyaan atau pernyataan mengenai variabel penelitian, mengenai efektivitas akun komunitas Instagram @1000_guru_bdg dalam pemenuhan kebutuhan informasi followers. Jawaban responden atas sejumlah pertanyaan dan pernyataan yang diajukan dalam kuesioner akan ditampilkan dalam bentuk tabel distribusi frekuensi dan persentase, dengan pengambilan kriteria sesuai hasil perhitungan.

Variabel Efektivitas akun komunitas Instagram @1000_guru_bdg terdiri dari Tabel 1 Kriteria Pengklasifikasian Presentase Skor Tanggapan Responden

\begin{tabular}{cc}
\hline Interval & Kategori \\
\hline $25,0 \%-43,75 \%$ & Sangat Tidak Efektif \\
$43,75 \%-62,50 \%$ & Tidak Efektif \\
$62,50 \%-81,25 \%$ & Efektif \\
$81,25 \%-100 \%$ & Sangat Efektif \\
\hline
\end{tabular}

Sumber: Olahan Penulis 2016

empat sub variabel yang diukur dengan 9 item pernyataan. Berikut ini akan disajikan distribusi frekuensi tanggapan responden mengenai efektivitas akun komunitas Instagram @1000 Guru_Bdg.

Tabel 2 merupakan rekapitulasi jawaban responden pada variabel pemanfaatan akun komunitas Instagram@1000_Guru_Bdg yang di ukur menggunakan empat sub variabel dengan 9 pernyataan. Berdasarkan tabel 2, terlihat 
Tabel 2 Rekapitulasi Skor Tanggapan Responden Terhadap Efektivitas Akun Komunitas Instagram@1000_Guru_Bdg

\begin{tabular}{ccccccc}
\hline No & Sub Variabel & Item & Skor Aktual & Skor Ideal & $\%$ & Kategori \\
\hline 1 & Pemahaman & 2 & 637 & 800 & 79,63 & Efektif \\
2 & Kepemenuhan Kesenangan & 1 & 310 & 400 & 77,50 & Efektif \\
3 & Memenuhi Sikap & 4 & 1252 & 1600 & 78,25 & Efektif \\
4 & Tindakan & 2 & 620 & 800 & 77,50 & Efektif \\
\hline & Total & 9 & 2819 & 3600 & 78,31 & Efektif \\
\hline
\end{tabular}

Sumber: Olahan Penulis 2016

bahwa perolehan nilai persentase tertinggi berada pada sub variabel pemahaman sebesar $79,63 \%$ sedangkan persentase terendah berada pada sub variabel kepemenuhan kesenangan dan sub variabel tindakan masing-masing sebesar $77,50 \%$. Secara keseluruhan dari tabel tersebut diketahui pula bahwa nilai persentase yang didapat pada variabel efektivitas akun komunitas Instagram @1000_guru_bdg sebesar $78,31 \%$.

Nilai 78,31\% pada gambar 1 berada pada interval $62,50 \%-81,25 \%$ yang tergolong efektif. Sehingga dapat diketahui bahwa efektivitas akun komunitas Instagram @1000_

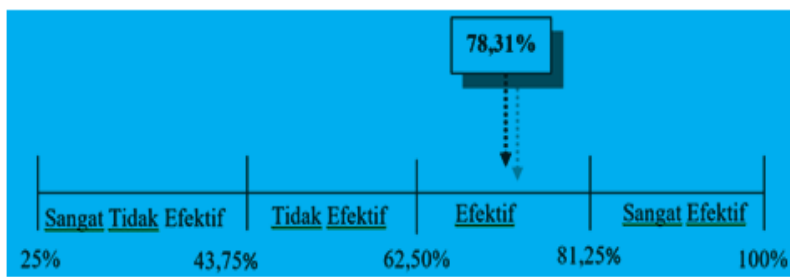

Sumber: Olahan Penulis 2016

\section{Gambar 1 Garis Kontinum Efektivitas Akun Komunitas}

guru_bdg sudah dinilai efektif atau tinggi.

Variabel pemenuhan kebutuhan informasi followers terdiri dari lima sub variabel yang diukur dengan 10 item pernyataan. Berikut ini akan disajikan distribusi frekuensi tanggapan responden mengenai pemenuhan kebutuhan informasi followers.

Tabel 3 Rekapitulasi Skor Tanggapan Responden Terhadap Pemenuhan Kebutuhan Informasi

\section{Followers}

\begin{tabular}{ccccccc|}
\hline No & Sub Variabel & Item & Skor Aktual & Skor Ideal & \% & Kategori \\
\hline 1 & Kebutuhan Kognitif & 2 & 615 & 800 & 76,88 & Efektif \\
2 & Kebutuhan Afektif & 3 & 935 & 1200 & 77,92 & Efektif \\
3 & Kebutuhan Integrasi Personal & 2 & 635 & 800 & 79,38 & Efektif \\
4 & Kebutuhan Integrasi Sosial & 1 & 319 & 400 & 79,75 & Efektif \\
5 & Kebutuhan Berkhayal & 2 & 599 & 800 & 74,88 & Efektif \\
\hline & Total & $\mathbf{1 0}$ & $\mathbf{3 1 0 3}$ & $\mathbf{4 0 0 0}$ & $\mathbf{7 7 , 5 8}$ & Efektif \\
\hline
\end{tabular}

Sumber: Olahan penulis 2016 
Tabel 3 merupakan rekapitulasi jawaban responden pada variabel pemenuhan kebutuhan informasi followers yang di ukur menggunakan lima sub variabel dengan 10 pernyataan. Berdasarkan tabel 3, terlihat bahwa perolehan nilai persentase tertinggi berada pada sub variabel kebutuhan integrasi sosial sebesar $79,75 \%$ sedangkan persentase terendah berada pada sub variabel kebutuhan berkhayal sebesar $74,88 \%$. Secara keseluruhan dari tabel tersebut diketahui pula bahwa nilai persentase yang didapat pada variabel pemenuhan kebutuhan informasi followers sebesar 77,58\%. Nilai $77,58 \%$ berada pada interval $62,50 \%-81,25 \%$ yang tergolong efektif. Sehingga dapat diketahui bahwa pemenuhan kebutuhan informasi followers sudah dinilai efektif atau tinggi.

Tabel 4 Kriteria Interpretasi Koefesien Korelasi/Hubungan

\begin{tabular}{cc}
\hline Rentang Interval & Kriteria \\
\hline $0,00-0,199$ & Sangat Rendah \\
$0,20-0,399$ & Rendah \\
$0,40-0,599$ & Sedang \\
$0,60-0,799$ & Kuat \\
$0,80-1,000$ & Sangat Kuat \\
\hline
\end{tabular}

Sumber: Sugiyono (2014: 184)

Analisis verifikatif dalam penelitian ini adalah untuk mengetahui efektivitas akun komunitas Instagram @1000_guru_bdg dalam pemenuhan kebutuhan informasi followers dengan menggunakan metode statistik koefisien korelasi pearson product moment dengan bantuan software SPSS v21, dan untuk melihat keeratan hubungan yang terjadi diantara variabel penelitian menggunakan kriteria menurut Sugiyono (2014: 184) ditunjukkan oleh tabel 4. Untuk mengetahui bagaimana pengaruh efektivitas akun komunitas Instagram @1000_guru_bdg dalam pemenuhan kebutuhan informasi followers, maka dilakukan analisis korelasi pearson product moment menggunakan bantuan software SPSS v21 dengan rumusan hipotesis sebagai berikut:

$$
\text { H0 }: \rho=0 ; \quad \text { Efektivitas akun }
$$

komunitas Instagram@1000_Guru_Bdg tidak berpengaruh signifikan dalam pemenuhan kebutuhan informasi followers.

Ha $: \rho \neq 0 ; \quad$ Efektivitas akun komunitas Instagram @1000_Guru_Bdg berpengaruh signifikan dalam pemenuhan kebutuhan informasi followers.

Kriteria : Tolak H0 jika thitung $>$ ttabel, terima Ha.

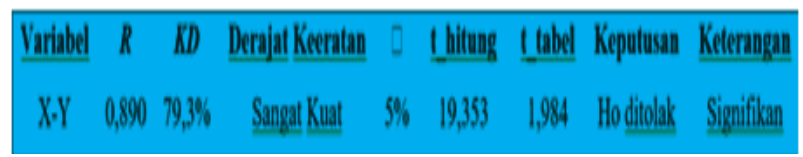

Sumber: Olahan Penulis 2016

Dari pernyataan tersebut dapat diketahui bahwa besarnya korelasi yang terjadi efektivitas akun komunitas Instagram @1000_Guru_ Bdg dalam pemenuhan kebutuhan informasi followers adalah sebesar tergolong sangat kuat dengan kontribusi sebesar 79,3\% sedangkan 
sisanya sebesar 20,7\% merupakan kontribusi dari variabel lain diluar penelitian. Hasil uji signifikansi diperoleh nilai thitung sebesar 19,535 dan nilai ttabel dengan $\alpha=5 \%$, untuk pengujian dua pihak sebesar 1,984. Dari keterangan-keterangan tersebut terlihat bahwa nilai t hitung lebih besar dari nilai t tabel $(19,353$ $>1,984)$ sehingga $\mathrm{H} 0$ di tolak dan Ha diterima.

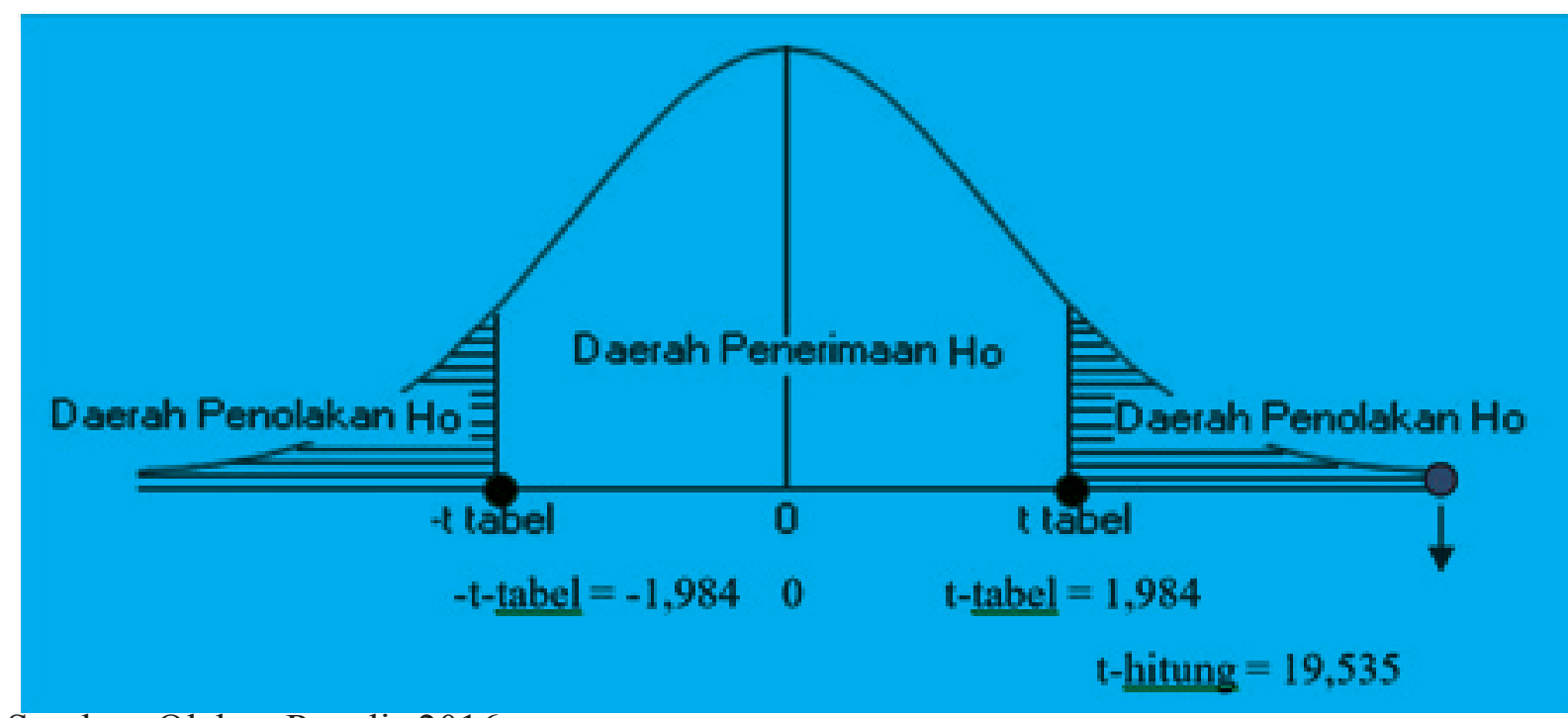

Sumber: Olahan Penulis 2016

\section{Gambar 2 Kurva Uji Hipotesis Mayor}

Dengan demikian maka dapat disimpulkan bahwa efektivitas akun komunitas Instagram @1000_guru_bdg berpengaruh signifikan dalam pemenuhan kebutuhan informasi followers dengan tingkat kepercayaan 95\%.

Untuk mengetahui bagaimana pengaruh pemahaman pada efektivitas akun komunitas Instagram @1000_guru_bdg dalam pemenuhan kebutuhan informasi followers, maka dilakukan analisis korelasi menggunakan pearson product moment dengan rumusan hipotesis sebagai berikut:

$$
\text { H0 : } \rho 1=0 ; \quad \text { Pemahaman pada }
$$

efektivitas akun komunitas Instagram @1000_ guru_bdg tidak berpengaruh signifikan dalam pemenuhan kebutuhan informasi followers.

$$
\text { Ha : } \rho 1 \neq 0 ; \quad \text { Pemahaman pada }
$$
efektivitas akun komunitas Instagram @1000_ guru_bdg berpengaruh signifikan dalam pemenuhan kebutuhan informasi followers.

Kriteria : Tolak H0 jika t hitung $>\mathrm{t}$ tabel, terima Ha.

\begin{tabular}{ccccccccc}
\hline Variabel & $\boldsymbol{R}$ & KD & Derajat Keeratan & t hitung & t tabel & Keputusan & Keterangan \\
\hline $\mathrm{X}_{1}-\mathrm{Y}$ & 0,746 & $55,7 \%$ & $\underline{\text { Kuat }}$ & $5 \%$ & 11,094 & 1,984 & Ho ditolak & $\underline{\text { Signifikan }}$ \\
\hline
\end{tabular}

Sumber:Olahan Penulis 2016 
Dari pernyataan tersebut dapat diketahui bahwa besarnya korelasi yang terjadi pemahaman pada efektivitas akun komunitas Instagram@1000_guru_bdg dalam pemenuhan kebutuhan informasi followers adalah sebesar 0,746 yang tergolong kuat dengan kontribusi sebesar 55,7\%. Sedangkan sisanya sebesar
44,3\% merupakan kontribusi dari faktor lain diluar penelitian. Hasil uji signifikansi diperoleh nilai thitung sebesar 11,094 dan nilai t tabel dengan $\alpha=5 \%$, untuk pengujian dua pihak sebesar 1,984. Dari keterangan-keterangan tersebut terlihat bahwa nilai t hitung lebih besar dari nilai t tabel $(11,094>1,984)$ sehingga $\mathrm{H} 0$ di

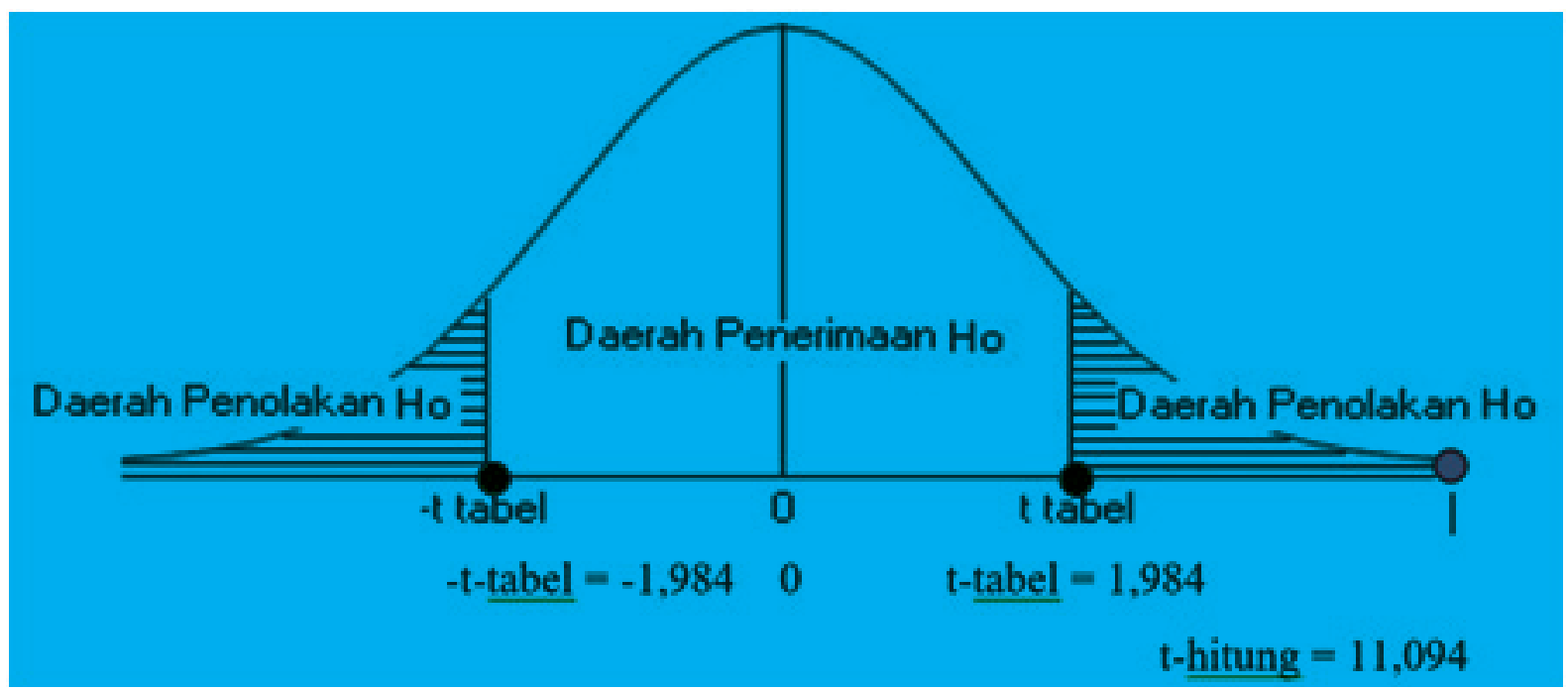

Sumber: Olahan Penulis 2016

\section{Gambar 3 Kurva Uji Hipotesis Minor 1}

tolak dan Ha diterima. Dengan demikian maka dapat disimpulkan bahwa pemahaman pada efektivitas akun komunitas Instagram @1000_ guru_bdg berpengaruh signifikan dalam pemenuhan kebutuhan informasi followers dengan tingkat kepercayaan 95\%.

Untuk mengetahui bagaimana pengaruh pemenuhan kesenangan pada efektivitas akun komunitas Instagram@1000_guru_bdg dalam pemenuhan kebutuhan informasi followers, maka dilakukan analisis korelasi menggunakan pearson product moment dengan rumusan hipotesis sebagai berikut:

$\mathrm{H} 0: \rho 2=0 ; \quad$ Pemenuhan kesenangan pada efektivitas akun komunitas Instagram @1000_Guru_Bdg tidak berpengaruh signifikan dalam pemenuhan kebutuhan informasi followers.

Ha : $\rho 2 \neq 0 ; \quad$ Pemenuhan kesenangan pada efektivitas akun komunitas Instagram @1000_Guru_Bdg berpengaruh signifikan dalam pemenuhan kebutuhan informasi 
followers.

Kriteria : Tolak H0 jika $\mathrm{t}$ hitung $>\mathrm{t}$ tabel, terima Ha.

Dari pernyataan tersebut dapat diketahui bahwa besarnya korelasi yang terjadi pemenuhan kesenangan pada efektivitas akun komunitas Instagram@11000_guru_bdg dalam pemenuhan kebutuhan informasi followers adalah sebesar 0,613 yang tergolong kuat dengan kontribusi sebesar 37,5\%. Sedangkan sisanya sebesar 62,5\% merupakan kontribusi dari faktor lain di luar penelitian.

Hasil uji signifikansi diperoleh nilai thitung sebesar 7,675 dan nilai ttabel dengan $\alpha=5 \%$, untuk pengujian dua pihak sebesar 1,984. Dari keterangan-keterangan tersebut terlihat bahwa nilai t hitung lebih besar dari nilai t tabel $(7,675$ $>1,984)$ sehingga H0 ditolak dan Ha diterima.

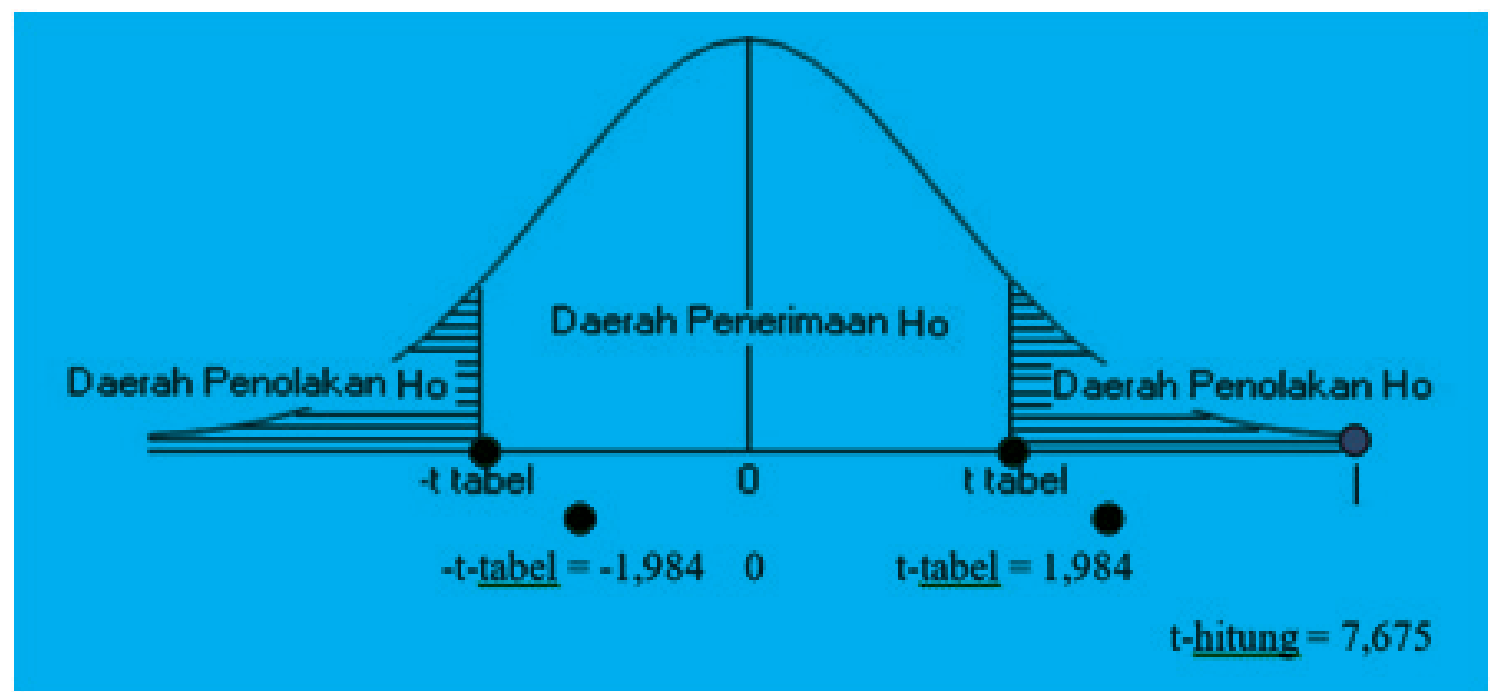

Sumber: Olahan Penulis 2016

\section{Gambar 4 Kurva Uji Hipotesis Minor 2}

Dengan demikian maka dapat disimpulkan bahwa pemenuhan kesenangan pada efektivitas akun komunitas Instagram @1000_Guru_Bdg berpengaruh signifikan dalam pemenuhan kebutuhan informasi followers dengan tingkat kepercayaan $95 \%$.

Untuk mengetahui bagaimana pengaruh pemenuhan sikap pada efektivitas akun komunitas Instagram@1000_Guru_Bdg dalam pemenuhan kebutuhan informasi followers, maka dilakukan analisis korelasi menggunakan pearson product moment dengan rumusan hipotesis sebagai berikut:

H0 : $\rho 3=0 ; \quad$ Pemenuhan sikap pada efektivitas akun komunitas Instagram @1000_ Guru_Bdg tidak berpengaruh signifikan dalam pemenuhan kebutuhan informasi followers.

Ha : $\rho 3 \neq 0 ; \quad$ Pemenuhan sikap pada efektivitas akun komunitas Instagram @1000_ guru_bdg berpengaruh signifikan dalam 


\begin{tabular}{|ccccccccc|}
\hline Variabel & $\boldsymbol{r}$ & KD & Derajat Keeratan & $\square$ & t hitung & t_tabel & Keputusan & Keterangan \\
\hline $\mathrm{X}_{\mathrm{3}} \mathrm{Y}$ & 0,876 & $76,7 \%$ & Sangat Kuat & $5 \%$ & 17.942 & 1.984 & Ho ditolak & Signifikan \\
\hline
\end{tabular}

Sumber: Olahan Penulis 2016

pemenuhan kebutuhan informasi followers.

Kriteria : Tolak H0 jika thitung $>$ ttabel, terima Ha.

Dari pernyataan tersebut dapat diketahui bahwa besarnya korelasi yang terjadi pemenuhan sikap pada efektivitas akun komunitas Instagram @1000_guru_bdg dalam pemenuhan kebutuhan informasi followers adalah sebesar 0,876 yang tergolong sangat kuat dengan kontribusi sebesar 76,7\% sedangkan sisanya sebesar $23,3 \%$ merupakan kontribusi dari faktor lain diluar penelitian. Hasil uji signifikansi diperoleh nilai t hitung sebesar 17,942 dan nilai t tabel dengan $\alpha=5 \%$, untuk pengujian dua pihak sebesar 1,984. Dari keterangan-keterangan tersebut terlihat bahwa nilai t hitung lebih besar dari nilai ttabel $(17,942$ $>1,984)$ sehingga H0 di tolak dan Ha diterima.

Dengan demikian maka dapat disimpulkan bahwa pemenuhan sikap pada efektivitas akun komunitas Instagram@1000_guru_bdg berpengaruh signifikan dalam pemenuhan kebutuhan informasi followers dengan tingkat kepercayaan $95 \%$.

Untuk mengetahui bagaimana pengaruh tindakan pada efektivitas akun komunitas Instagram@1000_guru_bdg dalam pemenuhan kebutuhan informasi followers, maka dilakukan

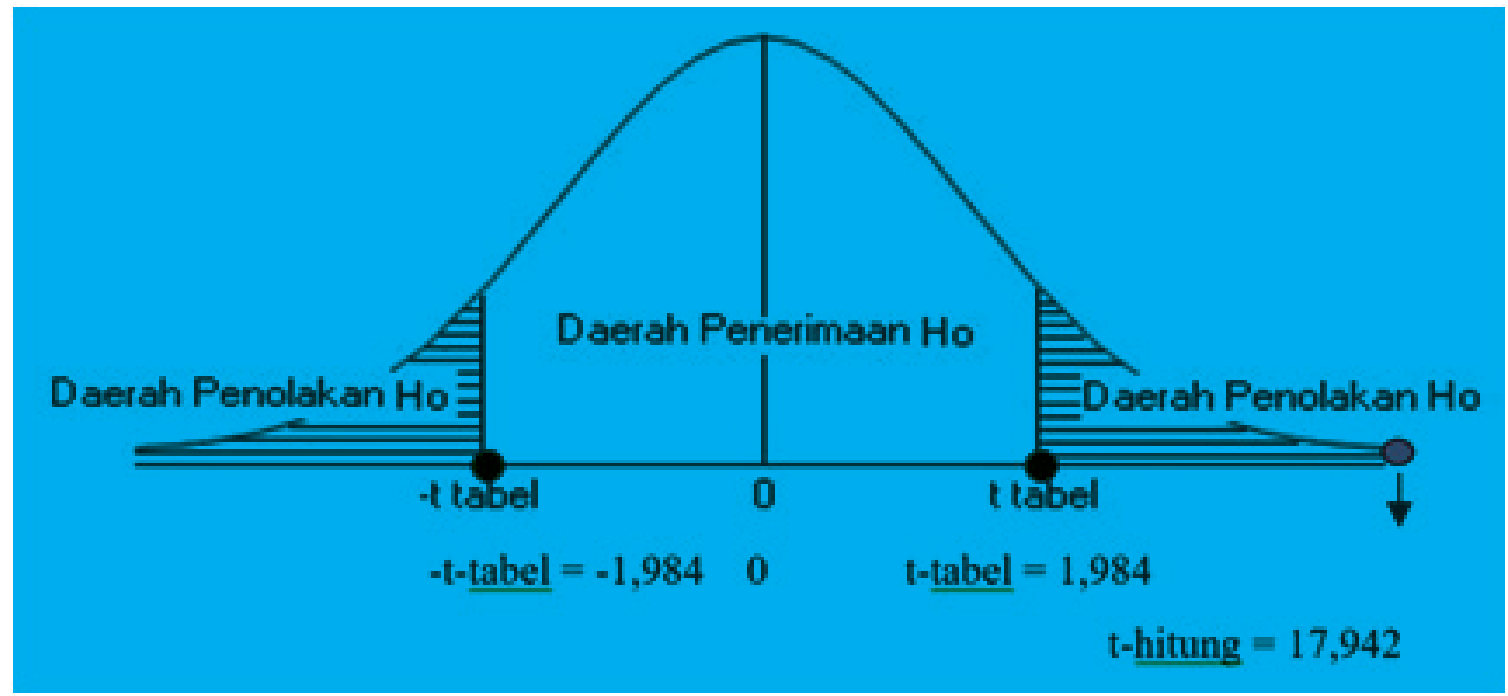

Sumber: Olahan Penulis 2016

\section{Gambar 5 Kurva Uji Hipotesis Minor 3}


analisis korelasi menggunakan pearson product moment dengan rumusan hipotesis sebagai berikut:

$$
\text { H0 : } \rho 4=0 ; \quad \text { Tindakan pada }
$$

efektivitas akun komunitas Instagram @1000_ Guru_Bdg tidak berpengaruh signifikan dalam pemenuhan kebutuhan informasi followers.
Ha : $\rho 4 \neq 0 ; \quad$ Tindakan pada efektivitas akun komunitas Instagram @1000_guru_bdg berpengaruh signifikan dalam pemenuhan kebutuhan informasi followers.

Kriteria : Tolak H0 jika thitung > ttabel, terima Ha.

Dari pernyataan tersebut dapat diketahui

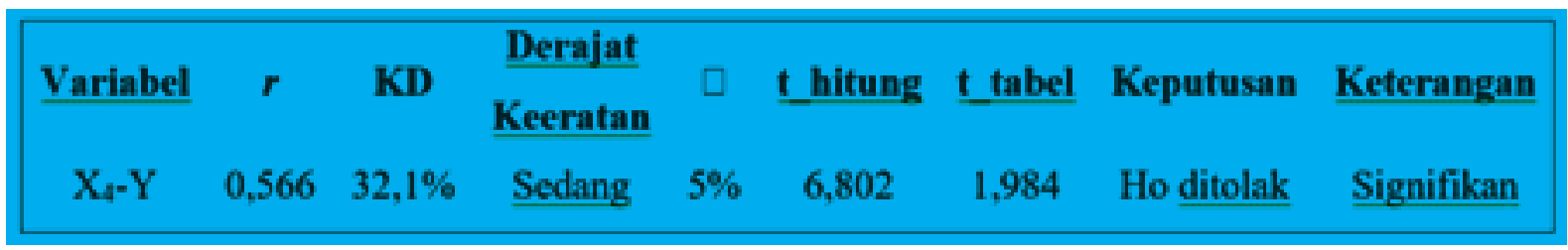

Sumber: Olahan Penulis 2016

bahwa besarnya korelasi yang terjadi tindakan pada efektivitas akun komunitas Instagram @1000_guru_bdg dalam pemenuhan kebutuhan informasi followers adalah sebesar 0,566 yang tergolong sedang dengan kontribusi sebesar $32,1 \%$ sedangkan sisanya sebesar $67,9 \%$ merupakan kontribusi dari faktor lain diluar penelitian. Hasil uji signifikansi diperoleh nilai t hitung sebesar 6,802 dan nilai t tabel dengan $\alpha=5 \%$, untuk pengujian dua pihak sebesar 1,984. Dari keterangan-keterangan tersebut terlihat bahwa nilai thitung lebih besar dari nilai ttabel $(6,802>1,984)$ sehingga H0 di tolak dan Ha diterima.

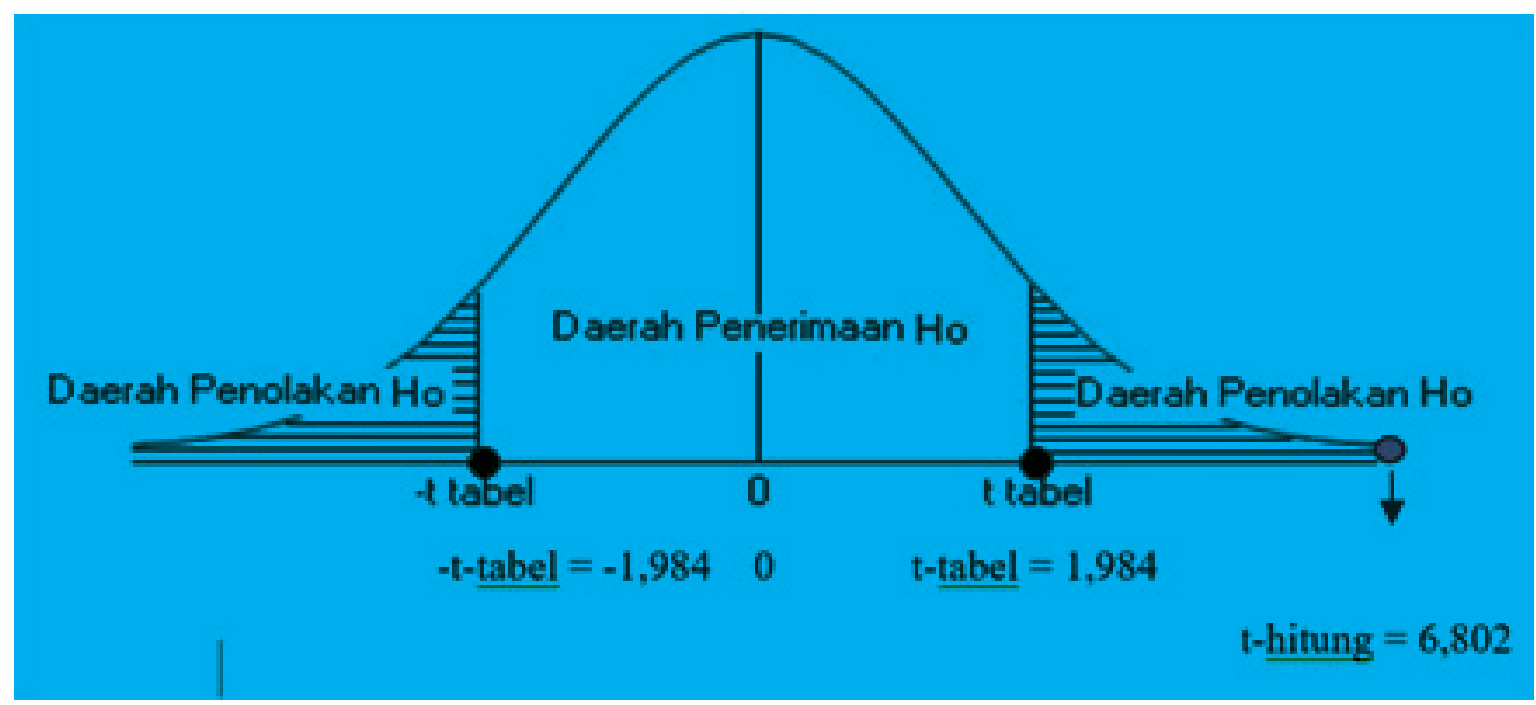

Sumber: Olahan Penulis 2016

\section{Gambar 6 Kurva Uji Hipotesis Minor 4}


Dengan demikian maka dapat disimpulkan bahwa tindakan pada efektivitas akun komunitas Instagram @1000_guru_bdg berpengaruh signifikan dalam pemenuhan kebutuhan informasi followers dengan tingkat kepercayaan $95 \%$.

\section{SIMPULAN}

Berdasarkan hasil analisis dan pembahasan tentang efektivitas akun komunitas Instagram @11000_guru_bdg dalam pemenuhan kebutuhan informasi followers mengenai kegiatan "Traveling \& Teaching", kesimpulan dari penelitian ini adalah kegiatan tersebut sudah efektif. Hal ini dibuktikan dengan adanya hasil pengukuran pada efektivitas menggunakan sub variabel dalam penelitian ini,yaitu terdiri dari pemahaman, pemenuhan kesenangan, memenuhi sikap, dan tindakan. Poin-poin yang digunakan dalam sub variabel pemenuhan kebutuhan informasi mencakup kebutuhan kognitif, kebutuhan afektif, kebutuhan integrasi personal, dan kebutuhan berkhayal.

Dari hasil pengukuran tersebut, peneliti mendapatkan bahwa hasil rekapitulasi skor tanggapan responden terhadap efektivitas akun komunitas Instagram @1000_guru_bdg (X) menyatakan bahwa perolehan nilai persentase tertinggi berada pada sub variabel pemahaman yaitu sebesar 79,63\% dan termasuk pada kategori efektif. Nilai tersebut didapatkan dari hasil kuisioner yang telah disebarkan kepada 100 responden. Dari hasil persentase, dapat diketahui bahwa poin utama komunikasi dapat dikatakan terpenuhi secara efektif, yaitu adanya pemahaman dari para followers dalam memahami pesan yang disampaikan kepada akun komunitas@1000_guru_bdg mengenai kegiatan "Traveling \& Teaching". Hal ini sesuai dengan yang dipaparkan oleh (Wahyudi, 1996: 67) bahwa komunikasi dikatakan efektif apabila pesan yang disampaikan kepada publik dapat diterima secara jelas, dimengerti, serta dipahami sebagai halnya yang dimaksud oleh pengirim pesan. Jika dihitung secara keseluruhan, nilai persentase yang didapat pada variabel efektivitas akun komunitas Instagram @11000_guru_bdg (X) adalah sebesar 78,31\%. Nilai 78,31\% berada pada garis interval 62,50 $81,25 \%$ yang merupakan kategori efektif.

Hasil rekapitulasi skor tanggapan responden terhadap pemenuhan kebutuhan informasi followers (Y) mengindikasikan bahwa perolehan nilai persentase tertinggi berada pada sub variabel kebutuhan integrasi sosial yaitu sebesar $79,75 \%$ dan termasuk pada kategori efektif. Dari hasil persentase, diketahui bahwa poin utama dalam pemenuhan kebutuhan informasi followers adalah adanya penguatan suatu hubungan baik dari media maupun followers dalam memberikan dan menerima informasi yang disampaikan 
kepada akun komunitas @1000_guru_bdg mengenai kegiatan "Traveling \&Teaching".. Namun, jika dihitung secara keseluruhan, maka nilai persentase yang didapat pada variabel pemenuhan kebutuhan informasi (Y) yaitu sebesar $77,58 \%$. Nilai $77,58 \%$ berada pada garis interval $62,50 \%-81,25 \%$ yang merupakan golongan efektif.

Pada hasil yang telah peneliti hitung dengan menggunakan software SPSS v21, maka diperoleh hasil yang menunjukkan nilai koefisien korelasi pada efektivitas akun komunitas Instagram @1000_guru_bdg dalam pemenuhan kebutuhan informasi followers yaitu sebesar $79,3 \%$ yang dapat diartikan bahwa hubungan korelasi antara (X) terhadap (Y) memiliki derajat keeratan yang sangat kuat. Nilai tersebut didapatkan pada koefisien determinasi. Selain itu peneliti juga menggunakan pengujian hipotesis mayor yang memiliki hasil uji signifikansi diperoleh nilai t hitung sebesar 19,535 dan nilai t tabel dengan $\alpha=5 \%$, untuk pengujian dua pihak sebesar 1,984. Dari keterangan-keterangan tersebut terlihat bahwa nilai t hitung lebih besar dari nilai t tabel $(19,353>1,984)$ sehingga H0 di tolak dan Ha diterima. Sehingga dapat disimpulkan bahwa efektivitas akun komunitas Instagram @1000_guru_bdg signifikan dalam pemenuhan kebutuhan informasi followers mengenai kegiatan "Traveling \& Teaching".
Berdasarkan hasil penghitungan, kebutuhan informasi yang telah disampaikan untuk followers mengenai kegiatan "Traveling \& Teaching" sudah efektif berlandaskan pada kebutuhan integritas sosial, dan pada efektivitas berlandaskan pada pemahaman isi pesan. Oleh sebab itu, pada penelitian ini diperoleh hasil bahwa semakin tinggi efektivitas maka semakin tinggi juga pemenuhan kebutuhan informasi.

\section{DAFTAR PUSTAKA}

Abidin, Y. Z. (2015). Manajemen komunikasi: filosofi, konsep dan aplikasi. Pustaka Setia: Bandung.

Abrar, A. N. (2003). Teknologi komunikasi perspektif ilmu komunikasi. Yogyakarta: LESFI.

Annisa. (2014). Potret pendidikan di indonesia. [Online] Available at: http: //www. seputarmalang.com/info/info-pendidikan/ potret-pendidikan-di-indonesia/11967 [Accessed 17 August 2016, 16: 10].

Arikunto, S. (2007). Prosedur penelitian suatu pendekatan praktik. Jakarta: Rineka Aksara.

Foss, L. 2009). Teori komunikasi. Jakarta: Salemba Humanika.

Geuit, Suwandi, Susie. (2017). Pembentukan brand awareness warunk indomie upnormal melalui food blogger. PRofesi Humas, Vol 1, No. 2.

Liliweri, A. (2015). Komunikasi antarpersonal. Jakarta: Prenadamedia Group,

Mulyana, D. (2008). Ilmu komunikasi suatu pengantar. Bandung: Remaja Rosdakarya Nasrullah, R (2014). Teori dan riset media siber. Jakarta: Kencana Prenadamedia Group. 
Putri, D. W., Hamdan, S. R., \& Yulianti. (2017). Perilaku bermedia digital dalam pelaksanaan tridarma perguruan tinggi di kalangan dosen Unisba. Jurnal Media Tor, 10 (1), 11-24.

Salim,A.(2001). Teoridan paradigmapenelitian sosial. Tiara Wacana: Yogyakarta.

Seribuguru. (2016). Traveling \& teaching. [Online] Available at: http://seribuguru. org/profile/tentang-kami/ [Accessed 17 August 2016, 11: 21].
Siregar, S. (2013). Metode penelitian kuantitatif dilengkapi dengan perbandingan perhitungan manual \& spss. Jakarta: Kencana Prenada Media Group.

Sugiyono. (2014). Metode penelitian kuantitatif, kualitatif dan $r \& d$. Bandung: Alfabeta.

Sukmadinata, N. S. (2013). Metode penelitian pendidikan. Bandung: Remaja Rosdakarya. Wahyudi, A. S. (1996). Manajemen strategik: pengantar proses berpikir strategik. Jakarta: Binarupa Aksara. 